\title{
Diagnostic Role of Circulating Immune Complexes During Cow Leukemia
}

\author{
Talgat R. Yakupov*, Mars M. Valiev², Farit F. Zinnatov', Albert K. Galiullin1, \\ Azat M. Alimov' ${ }^{1}$, Guzel N. Zainasheva ${ }^{3}$, Chulpan A. Kharisova ${ }^{1}$ \\ ${ }^{1}$ Kazan State Academy of Veterinary Medicine by N.E. Bauman, Sibirsky tract 35, Kazan city, Russia \\ ${ }^{2}$ Republican veterinary laboratory, Daurskaya street 34, Kazan city, Russia \\ ${ }^{3}$ Kazan State Power Engineering University, Krasnoselskaya street 51, Kazan city, Russia
}

\section{ABSTRACT}

In chronic infections caused by retroviruses, "antigen antibody" immune complexes (AAC) appear in body fluids. In the course of the studies to clarify the structure of the AAC we proved that immune complexes in cattle leukemia could contain the virus's viral DNA. The role of circulating immune complexes in the pathogenesis of the bovine leukemia virus (BLV) infection is not sufficiently studied. AAC containing the viral DNA may be formed during the death of infected B-lymphocytes by linking non-invasive viral DNA to surface IgMs with high DNA affinity. Determining the appearance of AAC with the viral DNA in biological fluids depending on the stages of the infectious process is an important criterion in antileukemia measures. The article describes the results of research to determine circulating immune complexes containing the provirus DNA in the milk of cows infected with BLV as compared with hematological changes at different stages of the infection process. It is reported that the viral DNA in the AAC of the milk of cows infected with BLV is detected much earlier than hematological changes that allow to consider them leukemia patients. Of the 12 cows studied, by the end of the experiment, six cows had AAC containing the viral DNA in their milk samples. And only one cow with the detection of the viral DNA in the AAC of milk showed parallel hematological changes typical for leukemia. The use of milk samples for molecular genetic analysis to identify BLV in AAC is quite a promising area for assessing the epizootic situation on farms and is very informative in determining the animal status.

KEY WORDS: BOVINE LEUKEMIA, POLYMERASE CHAIN REACTION, IMMUNOSORBENT ASSAY, PROVIRUS, IMMUNE COMPLEXES.

\section{INTRODUCTION}

Bovine leukemia virus is one of the most widespread chronic infectious diseases of farm animals not only in Russia, but all over the world. BLV infects livestock around the world and poses serious problems for livestock

\section{ARTICLE INFORMATION}

*Corresponding Author: Smolentsev82@mail.ru

Received 15th Oct 2020 Accepted after revision 18th Dec 2020

Print ISSN: 0974-6455 Online ISSN: 2321-4007 CODEN: BBRCBA

Thomson Reuters ISI Web of Science Clarivate Analytics USA and Crossref Indexed Journal

\section{Clarivate
Analytics}

NAAS Journal Score 2020 (4.31)

A Society of Science and Nature Publication,

Bhopal India 2020. All rights reserved.

Online Contents Available at: http//www.bbrc.in/

Doi: http://dx.doi.org/10.21786/bbrc/13.15/6 production (Ernst and Zinovieva, 2008), One of the factors inhibiting the effectiveness of health-improving measures in leukemia is the late diagnosis of the disease due to the use of methods that do not have high sensitivity and specificity, as well as due to insufficient study of the peculiarities of pathogenesis of the infectious process (Kalashnikova, 2003). As is known, diagnostic tests for leukemia are carried out using serological, molecular genetic, hematological and other methods (Khabibrakhmanova, 2009). The diagnosis of cattle leukemia is based on serological methods, which are based on the detection of specific antibodies to cattle leukemia virus antigens in animal blood serum (Balakirev et. al., 2018; Giblin et. al., 2010; Zinnatov et. al., 2017). 
However, the relationship between free and serumbound antibodies is constantly changing as the infection process progresses. Therefore, one-off serological tests in the diagnosis of cattle leukemia may not be effective enough. At present, along with serological methods of research, the use of polymerase chain reaction (PCR) in the diagnosis of cattle leukemia is regulated (Giblin et. al., 2010; Zinnatova et. al., 2014). It is also recommended that the detection of proviral load levels (PLV) be used as an indicator of animal infection in an antileukemia measures. Most retroviruses are considered to be infectious, and the relative amount of integrated provision in the host genome, known as the viral load (PVL), is associated with an increased risk of infection spread (Zinovyeva and Ernst, 2006).

In addition, it is known that in chronic infections caused by retroviruses, immune complexes "antigen-antibody" (AAC) appear in body fluids. Immune complexes in serum of infected BLV cows contain immunoglobulins $\mathrm{G}, \mathrm{M}$ and viral components. In studies to clarify the structure of AAC we proved that immune complexes in cattle leukemia may contain the virus's viral DNA
(Sukhareva and Gagloeva, 2008). Given that diagnostic measures for cattle leukemia in milk samples are more cost-effective, the purpose of this paper was to determine the dependence of the appearance of AAC in milk samples containing the viral DNA on the stages of the infection process.

\section{MATERIAL AND METHODS}

An experimental group of 12 cows infected in vivo was created from the first diagnosis of immunodiffusion reaction (IR) and confirmed by ELISA and PCR methods. Blood and milk samples were examined every 2 months to detect AC, the viral DNA and hematological changes. The immunoenzyme analysis was carried out using the "Antibody Detection Kit for Bovine Leukemia Virus (BLV)" produced by NPO "Narvak" according to the generally accepted method and with preliminary dissociation of AAC in samples. The results of IR studies were obtained from the Republican Veterinary Laboratory. PCR was set using reagents of the test system "Leukosis cattle provirus" for detection of the viral DNA in leukocytes and AAC of milk.

\begin{tabular}{|c|c|c|c|c|c|c|c|c|c|c|c|c|}
\hline \multirow[b]{3}{*}{ 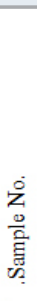 } & \multicolumn{12}{|c|}{ Research order, indicators } \\
\hline & \multicolumn{3}{|c|}{1} & \multicolumn{3}{|c|}{2} & \multicolumn{3}{|c|}{3} & \multicolumn{3}{|c|}{4} \\
\hline & 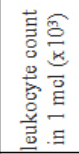 & 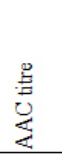 & 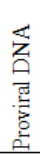 & 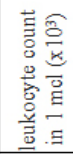 & 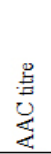 & 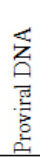 & 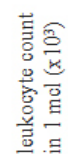 & 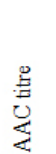 & 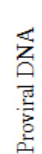 & 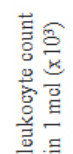 & 莺 & 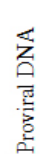 \\
\hline 1 & $\overline{9.7}$ & $1: 8$ & - & $\overline{9.1}$ & $1: 8$ & - & $9.8=$ & $1: 2$ & - & & $1: 4$ & 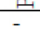 \\
\hline 2 & 10.2 & $1: 8$ & - & 9.9 & $1: 2$ & - & 10.1 & rel. & - & 10.1 & $1: 4$ & - \\
\hline 3 & 8.6 & $1: 2$ & - & 9.2 & $1: 8$ & + & 14.5 & $1: 8$ & + & 17.3 & $1: 8$ & + \\
\hline 4 & 8.9 & $1: 8$ & - & 8.9 & $1: 8$ & - & 9.2 & $1: 8$ & - & 9.9 & $1: 4$ & + \\
\hline 5 & 9.1 & rel. & - & 9.2 & $1: 2$ & - & 10.1 & $1: 4$ & - & 10.2 & $1: 2$ & + \\
\hline 6 & 9.5 & $1: 2$ & - & 8.9 & $1: 4$ & - & 9.9 & $1: 2$ & - & 9.8 & $1: 8$ & - \\
\hline 7 & 8.7 & $1: 8$ & - & 9.7 & $1: 4$ & + & 10.1 & $1: 2$ & + & 16.2 & $1: 8$ & + \\
\hline 8 & 8.8 & $1: 8$ & - & 10.1 & $1: 2$ & - & 10.1 & $1: 8$ & - & 10.3 & $1: 4$ & - \\
\hline 9 & 9.1 & $1: 16$ & - & 9.8 & $1: 8$ & - & 10.2 & $1: 16$ & - & 12.4 & $1: 4$ & + \\
\hline 10 & 8.8 & $1: 2$ & - & 8.7 & $1: 2$ & - & 9.8 & $1: 8$ & - & 9.8 & $1: 8$ & - \\
\hline 11 & 9.7 & $1: 16$ & - & 8.8 & $1: 8$ & - & 10.3 & $1: 8$ & - & 10.3 & $1: 2$ & - \\
\hline 12 & 10.1 & $1: 8$ & - & 9.5 & $1: 2$ & - & 9.9 & $1: 8$ & + & 16.8 & $1: 4$ & + \\
\hline
\end{tabular}

Circulating immune complexes were isolated by the method of precipitation in polyethylene glycol (PEG). At the same time, serum samples were mixed in a ratio of $1: 1$ with 7\% PEG-6000 solution in $0.1 \mathrm{M}$ borate buffer (pH 8.8), stirred and incubated at $+4{ }^{\circ} \mathrm{C}$ for 72 hours. The precipitate was precipitated by centrifugation at $5000 \mathrm{~g}$ for 20 minutes and washed three times with tenfold PEG volume in concentrations: $3.5 \%, 7 \%$ and $10.5 \%$ in borate buffer. The isolated immune complexes were dissolved in physiological solution and their activity in ELISA was studied. Counting of white blood cells was carried out in a counting chamber with Goryayev's grid. Animal leukemia status was determined based on the number of leukocytes and lymphocytes in $1 \mu$ l of animal blood according to the "leukemia key".

\section{RESULTS AND DISCUSSION}

In the experimental group of animals, observations were made throughout the year. Every two months, blood and milk samples were taken. The number of leukocytes in 1 $\mu \mathrm{l}$ of blood, the titers of circulating immune complexes in milk and the presence of viral DNA in AAC were determined. The research results are presented in the table. All cows of the experimental group from one herd, 2-4 years old, were diagnosed as infected with BLV for the first time, i.e. no more than 6 months had passed since the infection. As can be seen from the results of studies presented in the table, after the first and second studies the number of leukocytes in the blood of all experimental animals is within the physiological norm. Consequently, there are no hematologically ill animals.

It should be noted that in milk samples of all animals except No. 5 after the first study AAC containing antileukemia antibodies in titers from 1:2 to 1:16 were found, which later did not disappear in almost all animals during the whole experiment. The only exception is cow number 2, which was not found in the AAC sample for the third time (6 months later). The provirus DNA 
in the AAC of milk is detected for the first time in two cows under No. 3.7 for the second time, i.e. 4 months after the beginning of the studies. It is important to note that hematological indicators in those animals are currently within the physiological norm. Cow number 7 still has this indicator within the norm even after the third study.

After the third time or 6 months from the beginning of the experiment, the viral DNA in AAC of the milk is detected in another sample - No. 12. At the same time, hematological indicators are also within normal limits. 9.9 thousand leukocytes in $1 \mu \mathrm{l}$ of blood. It is known that according to the "leukemia key" in hematologically ill cows, at the age of 2-4 years, the content of leukocytes in $1 \mu \mathrm{l}$ of blood is more than 11 thousand. After the fourth time, only 6 samples of viral DNA in AAC of the milk are detected. Three of them, No. 4, 5, 9, have them first discovered. Only in cow No. 9, in parallel with the detection of the viral DNA in AAC of the milk hematological changes characteristic of leukemia also appeared. The content of leukocytes is more than 12 thousand per $1 \mu \mathrm{l}$ of blood.

According to the rules for the prevention and control of cattle leukemia, animals whose serums have given a positive result in IR or ELISA are considered to be infected with the leukemia virus and shall be examined every 6 months by a haematological method for leukemia. Animals with blood changes specific to leukemia are recognized as sick, isolated and slaughtered. According to the existing regulations, cattle infected with BLV can be used in economic needs in compliance with veterinary and sanitary rules. However, the discovery of AAC in blood and milk containing the viral DNA calls into question existing methods for the duration of possible animal exploitation and for recognition of animals as leukemia patients. Moreover, the ability of DNA to remain viable even after prolonged heat treatment is considered proven.

\section{CONCLUSION}

The role of circulating immune complexes in the pathogenesis of the bovine leukemia virus (BLV) infection is not sufficiently studied. AAC containing the viral DNA may be formed during the death of infected B-lymphocytes by linking non-invasive viral DNA to surface IgMs with high DNA affinity. It is obvious that they appear in milk in the later stages of the disease with a pronounced virus presence in the blood flow, when the animal becomes a potentially dangerous source of herd infection. Hematological changes during this period remain stable in most cases. The use of milk samples for molecular genetic analysis to identify BLV in AAC is quite a promising area for assessing the epizootic situation in farms and is very informative in determining the status of the animal, as well as the possibilities and duration of operation of the infected animal in production conditions. The results of the research give grounds to revise the criteria for an animal that is "infected" and "leukemia-positive".

\section{REFERENCES}

Balakirev, A.N., Safina, N.Yu., Yulmeteva, Yu.R., Shakirov, Sh.K., Zinnatova, F.F Association of leptin gene (LEP) polymorphism with the growth dynamics and dairy productivity of Holstein cow-heifers. Russian Agricultural Sciences. 2018; 4: 46-49. DOI 10.31857/ S250026270000535-3

Ernst, L.K., Zinovieva, N.A. Biological problems of livestock in the XXI century. M.: RAAS; 2008: 501.

Giblin, L., Butler, S., Kearney, B., Waters, S., Callanan, M., Berry, D. All Association of bovine leptin polymorphisms with energy output and energy storage traits in progeny tested Holstein-Friesian dairy cattle sires. BMC Genetics. 2010: 1-10. https://doi. org/10.1186/1471-2156-11-73

Kalashnikova, LA, Possibilities of using DNA markers of the productive qualities of animals in practical breeding work. Math. of the 3rd international scientific conference "Modern achievements and problems of biotechnology of farm animals". 2003: 33-39.

Khabibrakhmanova, Ya.A. Polymorphism of kappacasein and beta-lactoglobulin in Kholmogorsky cattle. Saransk, Mordovian Research Institute of Agriculture. 2009: 69-72.

Sukhareva, T.N., Gagloeva, T.N. Dairy business. Michurinsk. 2008: 70.

Zinnatov, F.F., Shamsova, A.R., Zinnatova, F.F., Akhmetov, T.M., Safiullina, A.R. Interrelation of polymorphism of lipid metabolism genes (LEP, TG5) with milk production of cattle. Scientific notes of Kazan Bauman SVAM. 2017; 231: 72-76.

Zinnatova, F.F., Alimov, A.M., Shakirov, S.K., Zinnatov, F.F. Study of the influence of complex gene genotypes CSN3, DGAT1, TG5, PRL, LGB on parameters parent index bulls. Questions of normative-legal regulation in the veterinary. $2014 ; 2: 120-123$.

Zinovyeva, N.A., Ernst, L.K. Problems of biotechnology and selection of farm animals. Dubrovitsy. 2006: 316. 